\title{
Hypopharyngeal Cancer TNM Finding v8
}

National Cancer Institute

\section{Source}

National Cancer Institute. Hypopharyngeal Cancer TNM Finding v8. NCI Thesaurus. Code C132910.

A finding about one or more characteristics of hypopharyngeal cancer, following the rules of the TNM AJCC V8 classification system. This staging system applies to all cancers of the hypopharynx. Minor salivary gland carcinomas and neuroendocrine carcinomas of the hypopharynx are included in this classification. (from AJCC 8th Ed.) 